\title{
Ecosystem development following deglaciation: a new sedimentary record from Devils Lake, Wisconsin, USA
}

\author{
Joseph J. Williams ${ }^{1 * \#}$, Kendra K. McLauchlan ${ }^{1}$, Joshua R. Mueller ${ }^{1}$, Emily M. Mellicant ${ }^{2}$, \\ Amy E. Myrbo ${ }^{3}$ and Ioan Lascu ${ }^{3,4, \S}$ \\ ${ }^{1}$ Department of Geography, Kansas State University, 118 Seaton Hall, Manhattan, \\ Kansas, USA 66506 \\ ${ }^{2}$ Rosenstiel School of Marine and Atmospheric Science, University of Miami, 4600 \\ Rickenbacker Causeway, Miami, Florida, USA 33149 \\ ${ }^{3}$ LacCore/CSDCO/Limnological Research Center, Department of Earth Sciences, \\ University of Minnesota, 500 Pillsbury Drive SE, Minneapolis, Minnesota, USA 55455 \\ ${ }^{4}$ Institute for Rock Magnetism, Department of Earth Sciences, University of Minnesota, \\ 100 Union Street SE, Minneapolis, Minnesota, USA 55455 \\ * Present address: Department of Geography and Earth Sciences, Aberystwyth \\ University, Aberystwyth, SY23 3DB, Wales, UK \\ $\S$ Present address: University of Cambridge, Department of Earth Sciences, Cambridge, \\ CB2 3EQ, United Kingdom \\ \# Corresponding author
}




\section{Abstract}

2 Processes and rates of ecosystem development can be reconstructed using lacustrine

3 sedimentary sequences, but this approach often requires records that contain the start of

4 primary succession. Most lakes in the upper Midwestern U.S. were formed by glaciers at the end

5 of the last Ice Age approximately 11,700 cal yr BP. Devils Lake, Wisconsin is a rare example of a

6 lake from this region whose sediments extend into the Pleistocene and may include the Last

7 Glacial Maximum. Sediment magnetic, geochemical, pollen, and charcoal records were

8 generated from a 10 meter core whose basal sediments may be 28,000 years old. Together with

9 a previously published pollen record, these proxies combine to reveal a history of long-term

10 climatic, vegetative and geologic change during the late Pleistocene to Holocene. We identify six

11 sedimentary units that indicate a series of consecutive events rather than a predictable

12 trajectory of ecosystem development at the site. Productivity in the lake was low during the late

13 Pleistocene and increased during the Holocene, as reflected by the sediment lithology, which

14 shows a sudden shift from glacial vivianite-rich and organic-poor clastic-dominated sediments to

15 Holocene diatomaceous sapropels. Several important processes initiated around 17,000 cal yr

$16 \mathrm{BP}$, including the onset of organic matter accumulation and fire in the terrestrial ecosystem.

17 However, the post-glacial landscape was not devoid of vegetation because pollen assemblages

18 indicate that terrestrial vegetation, likely a spruce tundra, survived near the site. A switch to a

19 hardwood forest period during the Holocene also led to a change in the fire regime, with

20 increased frequency of burning. Aquatic ecosystem productivity lagged terrestrial ecosystem

21 productivity throughout the record. Nutrient cycling (as recorded by sedimentary $\delta^{15} \mathrm{~N}$ ) was

22 variable but not directional, and appeared to be correlated with climate conditions early in the

23 record, and terrestrial ecosystem processes later in the record. Throughout the Holocene

24 magnetic mineral concentration decreased as productivity increased, and the source of

25 magnetic material shifted from almost exclusively lithogenic to approximately $50 \%$ derived from

26 soil or biogenic sources. Magnetic grain size, Ambrosia pollen percentages, and charcoal

27 concentration increased and $\delta^{15} \mathrm{~N}$ decreased in the most recent part of the record, due to

28 anthropogenic influence in the region including agricultural activities.

29

30 Keywords: climate; vegetation; fire; Holocene; mineral magnetism; primary succession;

31 stable isotopes 


\section{1. Introduction}

33 Theories about the nature and mechanisms of ecosystem change have been

34 developed from chronosequences (Jenny 1941), whereby sites substitute for time since

35 the start of primary succession. Different absolute rates but similar sequences of

36 biogeochemical events have been observed on chronosequences formed by a variety of

37 processes such as aeolian transport, wildfire, volcanic lava flow, uplift of marine terraces,

38 and glacial retreat (Wardle et al. 2004). Sedimentary archives have the potential to

39 provide continuous records of ecosystem development with excellent chronological

40 control. One of the few examples of a chronosequence paired with sedimentary

41 palaeorecords focused on nutrient cycling in lakes and landscapes of Glacier Bay, Alaska

42 following recent glacial retreat (Engstrom et al. 2000). In this case, although in a

43 relatively cold climate, the entire sequence from bare rock to old-growth conifer forest

44 took only 150 years (Milner et al. 2007).

45 From individual sedimentary palaeorecords spanning several millennia, the main

46 trajectories of ecosystem change seem to be establishment of vegetation and broadly

47 predictable increases in ecosystem productivity, biomass, and nutrient availability. Thus,

48 primary succession processes are dominated by accumulation of organic matter during

49 the Holocene (Mourier et al. 2010), and sometimes much longer timescales

50 (Finkenbinder et al. 2014), but the rates and controls of these processes are largely

51 unknown. Trajectories of both eutrophication and dystrophication have been observed

52 on Holocene timescales in sediments of oligotrophic lakes (Oldfield et al. 2010).

53 Additionally, ecosystem feedbacks with fire regimes and the relative roles of vegetation

54 and climate change on biogeochemical processes are not well studied. The most recent

55 glaciation of North America, the retreat of the Laurentide Ice Sheet, and the formation

56 of lakes with sedimentary sequences provide an opportunity to examine primary

57 ecosystem development.

58 Devils Lake, Wisconsin, USA has been a key location for understanding long-term

59 environmental changes across a transition zone between grassland and forest (Maher

60 1982). The lake and surrounding landscape underwent significant and complex changes 
61 during the last glacial period, followed by deglaciation and transition into the Holocene

62 period (Attig et al. 2011). Earlier debate focused on the vegetation composition during

63 the cool Younger Dryas (YD) interval (12.8 to 11.5 ka) (Baker et al. 1992, Shuman et al.

64 2002, Grimm et al. 2009). High temporal resolution pollen analysis provided a detailed

65 vegetation history, which was primarily interpreted as responding to climate changes,

66 but no other ecosystem proxies have been measured at this site. Importantly, Devils

67 Lake is situated on the boundary between the glaciated and non-glaciated areas of

68 southwestern Wisconsin. This non-glaciated terrain, known as the Driftless Area,

69 contains very few sites with continuous deposition (Maher 1982), so the sedimentary

70 archive from Devils Lake has long been acknowledged as a key palaeoenvironmental

71 record (Trowbridge 1917).

72 Because of its unusual setting (Lytwyn 2010, Attig et al. 2011), Devils Lake has

73 the potential to provide information about very early post-glacial ecosystem

74 development, as well as additional information about the biogeochemical changes

75 coinciding with previously documented climate and vegetation changes. We present

76 geochemical, biological, and geophysical data from a new, $\sim 10 \mathrm{~m}$ long sediment core

77 retrieved in February 2012 that describe the evolution of the catchment ecosystem. We

78 chose proxies that complement the detailed pollen record and provide information

79 about sediment sources, organic matter, nutrient cycling, and important terrestrial

80 ecosystem processes like fire. Collectively, these proxies combine to reveal a history of

81 long-term climatic, vegetative and geologic change within this region during the crucial

82 Pleistocene to Holocene transition. Additionally, this record provides further

83 information on the timing and rate of primary succession processes as well as

84 interactions with biotic and climatic drivers during the Holocene.

85

\section{2. Regional Setting and Study Site}

87 Devils Lake, Sauk County, Wisconsin $\left(43^{\circ} 25.08^{\prime} \mathrm{N}, 89^{\circ} 43.92^{\prime} \mathrm{W}, 294 \mathrm{~m}\right.$ asl) lies in a

88 stream-cut, Precambrian quartzite gorge within the Baraboo Hills syncline (Lytwyn 2010),

89 although the presence of sandstone proximal to the current lake levels does suggest 
90 that a depression previously existed (Trowbridge 1917). The gorge is constrained by

91 exposed, steep, rocky bluffs on the east, west and south sides (Lillie and Mason 1986)

92 that are up to $150 \mathrm{~m}$ above the current lake level (Fig. 1). The lake was formed when the

93 northern and southeastern ends of the Devils Lake Gorge were plugged by the

94 Johnstown moraine, deposited at the maximum extent of the Green Bay Lobe. It is likely

95 that Devils Lake became a continually inundated basin by 21,000 cal yr BP but certainly

96 by 18,500 cal yr BP, when OSL ages of sediment deposits suggest the Green Bay Lobe

97 began thinning and retreating (Attig et al. 2011). Independent radiocarbon dating of

98 lacustrine sediments just south of Devils Lake indicates that the position of ice here

99 during the glacial maximum may have been quite prolonged, with the Green Bay Lobe at

100 its maximum position from about $26,400 \pm 5,100$ cal yt BP to $21,400 \pm 3,300$ cal yr BP

101 (Carson et al. 2012). Further, there may have been extremely rapid collapse of the

102 Green Bay Lobe after this point as inferred from available and nearby radiocarbon

103 evidence (Maher and Mickelson 1996).

105 Today the Johnstown moraine at the north end is approximately 20-26 $\mathrm{m}$ high (above 106 the water level) and $0.3 \mathrm{~km}$ wide, and 25-35 $\mathrm{m}$ high and $1 \mathrm{~km}$ wide at the southeastern 107 end (Clayton and Attig 1990). Presently, Devils Lake has a maximum water depth of 14 $108 \mathrm{~m}$ and surface area of 153 ha. Two small springs are the only sources of surface inputs, 109 and there are no surface outflows. The lake is dimictic, with turnover occurring in spring 110 and autumn, and exhibits seasonal hypolimnetic anoxia. The geochemistry of Devils Lake

111 is similar to lakes in northern Wisconsin due to the outcrops of Baraboo quartzite in the

112 watershed, with relatively low acid neutralizing capacity (Herrin et al. 1998).

\section{3. Methods}

\section{$115 \quad 3.1$ Field sampling}

116 A sedimentary sequence of $10.40 \mathrm{~m}$ was extracted from the deepest part of Devils Lake 117 in February 2012. The coring location was chosen at the greatest water depth, located 118 using a handheld GPS with reference to previously conducted bathymetric surveys (Fig. 
119 2). Two overlapping piston cores (NICE-EVIL12-1A and NICE-EVIL12-1B) were recovered

120 using a modified Livingstone-type square-rod piston corer (Wright 1967) with staggered

121 starting depths. The overlap ensured that the entire lacustrine sedimentary section was

122 collected despite potential loss from core tube ends and unrecognized gaps between

123 successive sections.

124

125 Sediments were extruded from the steel barrel of the corer into acrylonitrile butadiene

126 styrene (ABS) casing, securely wrapped and transported to the LacCore facility and kept

127 in cold storage. The uppermost sediments (first 2 drives) were obtained using the Bolivia

128 modification in which $1.5 \mathrm{~m}$ polycarbonate core tubes are used. In this case, sediment

129 was not extruded in the field and the polycarbonate tubes were sealed on site. In order

130 to preserve the sediment/water interface of the initial core drive, sodium polyacrylate

131 powder was added to gel overlying water and "fix" these uppermost sediments.

\section{$133 \quad 3.2$ Sediment description and spectral analysis}

134 Cores were split and imaged before oxidation of the sediments could occur using a

135 Geoscan-III line-scanner. Glare was eliminated by the employment of polarizing filters

136 on the camera and light source. Initial core description was undertaken to further

137 document the sedimentary characteristics using a common classification scheme

138 (Schnurrenberger et al. 2003) and the Munsell Soil Color Charts. Mineral identity and

139 sediment composition were assessed by examination under a polarizing microscope

140 using smear slides and the TMI (Tool for Microscopic Identification; Myrbo et al. 2011).

142 Accurate colour properties were recorded at the imaging stage of sediment

143 documentation. Cores were imaged alongside a standard 24 colour card to allow for

144 necessary calibration. Separate values for red (R), green (G) and blue (B) color intensities

145 were recorded at a resolution of $0.01 \mathrm{~cm}$. All three colour intensities show a similar

146 variance so the mean red, green and blue (RGB) values are discussed here. Except in

147 unusual circumstances (Moy 2002), spectral properties are often controlled by organic 
148 content (Nederbragt et al. 2006), with a strong relationship observed between the

149 colour of the sediment and the total organic carbon (TOC) present (Williams et al. 2011).

\section{$151 \quad 3.3$ Chronology}

152 The sediment chronology was based upon ${ }^{14} \mathrm{C}$ accelerator mass spectrometry (AMS)

153 dating of six organic samples from the sedimentary sequence as well as the sediment-

154 water interface (Table 1). Samples were analysed at the Center for Accelerator Mass

155 Spectroscopy at Lawrence Livermore National Laboratory, U.S.A. Ages were calibrated

156 using the IntCal13 radiocarbon calibration curve (Reimer et al. 2013) and the age model

157 was developed using Bayesian age modeling in the Bacon package in $R$ [Version 2.2]

158 (Blaauw and Christen 2011). A depositional rate of 35 years $/ \mathrm{cm}$ was used as the prior in

159 the Bacon program. This rate was based upon the previous core from Devils Lake

160 (Grimm et al. 2009) and other records from the region (Goring 2012). Maximum

161 probability age estimates were returned for each $0.5 \mathrm{~cm}$ interval. All ages refer to

162 calendar years before present (BP), where present refers to 1950 C.E. As such, the most

163 modern sediments have dates of negative years BP (e.g. -50 year $B P=2000$ C.E.). All

164 dates discussed are expressed as calibrated years before present (cal yr BP).

166 Inspection of the sediment and the results of the AMS dating reveal that there are no

167 hiatuses or breaks in deposition since the accumulation of material began. High

168 confidence in the sediment integrality and the low analytical uncertainly of the ${ }^{14} \mathrm{C}$ ages

169 allowed all dates, except one (CAMS-160885), to be incorporated into the age-depth

170 model. The highest chronological uncertainty is for the lowest portion of the core below

$171751 \mathrm{~cm}$, the depth of the oldest radiocarbon date. Exceptionally low quantities of

172 material to obtain ${ }^{14} \mathrm{C}$ ages make it virtually impossible to determine the ages of these

173 oldest sediments. The maximum and minimum ages for the lowest sampled interval of

174 the sediment core $(1040 \mathrm{~cm})$ are 33,585 and 23,175 cal y BP. If the age model is

175 extended to the base of the core, the mean age at the lowest sampled interval of the

176 sediment core is $28,056 \mathrm{cal}$ yr BP. Because of this high chronological uncertainty at 
177 depth, we use the age model only to a mean age of 18,468 cal yr BP $(769 \mathrm{~cm})$, when the

178 range between the maximum and minimum age ( $95 \%$ confidence level, $2 \sigma)$ is 5546 years.

179 We report our results for the lowest $270 \mathrm{~cm}$ of the sediment core on a depth scale. This

180 enables a temporal context for post-maximum ice sheet events and dynamics that were

181 previously untimed but postdate $18,500 \mathrm{cal}$ yr BP (Attig et al. 2011).

182

183 To provide the most accurate comparison between the new 2012 core and the previous

184 core obtained by Maher (1982), the chronology developed by Grimm et al. (2009) was

185 recalibrated using the IntCal13 radiocarbon calibration curve (Reimer et al., 2013) and

186 ages calculated by Bayesian age modeling in the Bacon software in R (Blaauw and

187 Christen, 2011).

188

\section{$189 \quad 3.4$ Charcoal}

191 Charcoal analysis was conducted at the Palaeoenvironmental Laboratory at Kansas State

192 University following a modified version of the procedure described by (Long et al. 1998).

193 Subsamples $\left(2 \mathrm{~cm}^{3}\right)$ were taken at contiguous 1-cm intervals for macroscopic charcoal

194 analysis. Sediments were treated with a $10 \%$ solution of $\mathrm{H}_{2} \mathrm{O}_{2}$ for $48-72$ hours, before

195 being sieved and separated into two size fractions ( $>250$ and 125-249 $\mu \mathrm{m}$ ). Samples

196 were then suspended in water on a gridded Petri dish and counted using a binocular

197 microscope at 25-75× magnification. A distinction was made between arboreal (dark,

198 lattice and branched) and non-arboreal (cellular, fibrous) fragments based upon

199 morphology (Jensen et al. 2007). Charcoal morphotypes have been increasingly used to

200 infer fuel sources for past fires, with the ratio of non-arboreal to total charcoal

201 indicating the proportion of woody fuels (Mueller 2014). This ratio ranges from 0 to 1.

202 Low ratios of non-arboreal to total charcoal in sedimentary samples indicate woody fuel

203 sources, while high ratios indicate herbaceous fuel sources such as grasses and forbs. 
205 Charcoal counts were converted into concentration (particles $\mathrm{cm}^{-1}$ ) and, using the 206 sediment deposition rate, to charcoal accumulation rates (CHAR, particles $\mathrm{cm}^{-1} \mathrm{a}^{-1}$ ).

207 Charcoal data were then separated in background and peak components using the 208 model CharAnalysis Version 1.1 (Higuera et al. 2009). Background CHAR (changes in fuel 209 abundance and composition) is determined using a LOWESS smoother robust to outliers 210 with a 500-year moving window width and these values are then subtracted from the 211 total CHAR for each interval to provided a record of CHAR peaks (multiple closely timed 212 fires). The peaks are tested for significance using a Gaussian distribution, where peak 213 CHAR values that exceed the 95th percentile are then considered statistically significant. 214 Peaks are then screened to eliminate those that resulted from statistically insignificant 215 variations in CHAR (Gavin et al. 2006). In addition, peaks will be excluded if the 216 maximum count in a CHAR peak has a $>5 \%$ chance of coming from the same Poisson217 distribution population as the minimum charcoal count with the proceeding 75 years. 218 (Higuera et al. 2009).

\subsection{Pollen}

221 The primary pollen stratigraphy of the site was established using a sediment core 222 obtained in 1978 and reported in Maher 1982 and Baker et al. 1993. There were 122 223 samples analysed from this sediment core, making it one of the highest resolution 224 pollen records obtained from North America. The 2012 cores were subsampled $\left(1 \mathrm{~cm}^{3}\right)$ 225 for pollen and spore analysis, and after spiking with a microsphere solution, which 226 allows for the calculation of concentration data, chemical preparation followed standard 227 palynological protocol and was completed at the LacCore facility. Samples were 228 mounted in silicon oil and counted using 400X magnification. A minimum of 300 229 terrestrial fossil grains were analysed in each sample, except for the heavily degraded 230 samples. The pollen assemblages from samples from the 2012 core match pollen 231 assemblages from the 1978 core, where they overlap. Note that only six new samples 232 were analysed and reported here, all below $711 \mathrm{~cm}$. Because the original pollen 233 stratigraphy and core chronology were so robust, we report here only these six 
234 additional samples in the lowest portions of the 2012 core that predate samples from

235 the 1978 core. Percentage values for pollen grains were calculated relative to the pollen

236 sum as reported by Baker et al. 1982.

237

\section{$238 \quad 3.6$ Magnetic parameters}

239

240 Magnetic parameters in lake sediments are sensitive to changes both external and

241 internal environmental conditions. Concentration-dependent parameters, such as $\chi$,

242 ARM, IRM, saturation remanence $\left(M_{r s}\right)$, or saturation magnetisation $\left(M_{s}\right)$ reflect the

243 amount of mineral material contained in the sediment. Interparametric ratios such as

$244 \chi_{\mathrm{ARM}} / \mathrm{IRM}$ and $\mathrm{M}_{\mathrm{rs}} / \mathrm{M}_{\mathrm{s}}$ are indicative of magnetic particle grain size, which also reflects

245 climatic and environmental processes.

247 Volume-normalised magnetic susceptibility $(\kappa)$ was measured using the Bartington point

248 sensor (MS2E) attached to the automated Geotex MSCL-XYZ logger at the LacCore

249 facility. Measurements of the exposed surface of the split sediment cores were made at

250 a resolution of $0.5 \mathrm{~cm}$. All other magnetic parameters were measured at the Institute for

251 Rock Magnetism at the University of Minnesota. Subsamples were taken at $5 \mathrm{~cm}$

252 intervals. Wet samples with volumes of approximately $5 \mathrm{~cm}^{3}$ were freeze-dried and

253 measured for the following magnetic parameters: mass-normalised magnetic

254 susceptibility $(\chi)$, anhysteretic remanent magnetisation (ARM), isothermal remanent

255 magnetisation (IRM), and hysteresis parameters. $\chi$ was measured on a Kappabridge KLY-

2562 susceptometer operating at a frequency of $920 \mathrm{~Hz}$. Remanence measurements were

257 performed using a $2 \mathrm{G}$ superconducting rock magnetometer. A D-Tech 2000

258 demagnetiser was used for the acquisition of ARM in a $0.1 \mathrm{mT}$ direct field superimposed

259 on an alternating frequency field decaying at a rate of $5 \mu \mathrm{T}$ per half cycle from a peak

260 value of $200 \mathrm{mT}$. ARM susceptibility $\left(\chi_{\text {ARM }}\right)$ was calculated by dividing the ARM to the

261 direct field. IRM was imparted using an ASC Scientific IM-10 30 impulse magnetiser, by

262 exposing the samples to a $200 \mathrm{mT}$ direct field. This measurement was repeated to 
263 remove any viscous effects. The ARM ratio $\left(\chi_{A R M} / \mathrm{IRM}\right)$ of each sample was computed by

264 normalising the ARM susceptibility to the IRM.

265

266 The ferrimagnetic particle assemblage was modeled using a three end-member mixing

267 model based on bulk remanence and hysteresis parameters (Lascu et al. 2010; 2012).

268 The three end members were assigned the names BIO, PED, and LITH, and represent

269 biogenic, pedogenic, and lithogenic ferrimagnetic components, respectively, each with

270 distinct pairs of $\mathrm{M}_{\mathrm{rs}} / \mathrm{M}_{\mathrm{s}}$ and $\chi_{\text {ARM }} /$ IRM values (Fig.5; Lascu et al. 2010).

271

272 The BIO end member ratios were set at $\mathrm{M}_{\mathrm{rs}} / \mathrm{M}_{\mathrm{s}}=0.45$ and $\chi_{\text {ARM }} / \mathrm{IRM}=2 \mathrm{~mm} / \mathrm{A}$,

273 representative of weakly interacting single domain (SD) particles typical of magnetite

274 grains a few tens of nanometers in size produced by magnetotactic bacteria. These

275 grains are an in-lake source of magnetite, and are synthesised intracellularly by the

276 bacteria, which align them in chains. After the death of the microorganism, the

277 magnetite crystals are preserved in the sediment either as intact or partially collapsed

278 chains.

279

280 The PED end member ratio values were set at $M_{r s} / M_{s}=0.2$ and $\chi_{\text {ARM }} / I R M=0.01 \mathrm{~mm} / A$, 281 which are representative of i) small pseudo-single domain (PSD) magnetic particles, a

282 few micrometers in size (Lascu et al. 2010), ii) strongly interacting SD particles (Harrison

283 and Lascu, in press), or iii) a mixture thereof. This component is sourced in the

284 catchment soils, where magnetite is precipitated either abiotically or via dissimilatory

285 bacterial iron reduction. In either case the resulting grain size assemblage comprises

286 tight clumps of particles ranging from nanometer- to micrometer-sized. These

287 pedogenic particles typically reach the lake water via overland flow and runoff, with

288 aeolian pathways being a minor contributor.

289

290 The LITH end member ratio values were set at $M_{\mathrm{rs}} / \mathrm{M}_{\mathrm{s}}=0.05$ and $\chi_{\text {ARM }} / \mathrm{IRM}=0.01 \mathrm{~mm} / \mathrm{A}$,

291 which are representative of magnetite particles with an average grain size of a few tens 
292 of micrometers. The source of these larger particles is in crystalline or sedimentary

293 bedrock, and transport to the lake is accomplished by streams and/or wind.

\subsection{Organic geochemistry}

296 Organic carbon $(C)$ and nitrogen $(N)$ concentrations and standard isotopic ratios $\left(\delta^{13} \mathrm{C}\right.$, $297 \delta^{15} \mathrm{~N}$ ) were measured on dried bulk sediment samples every $10 \mathrm{~cm}$ (Fig. 6). Although 298 carbonate content in the sediments was known to be very low from previous analyses, 299 there is some carbonate present in the lower portions of the sediment core due to 300 aeolian activity and transport in the region (Grimm et al. 2009). Therefore, inorganic

301 carbon was removed prior to isotopic analysis using acid pretreatment for sedimentary 302 samples below $550 \mathrm{~cm}$. Analyses were conducted at the Stable Isotope Mass

303 Spectrometry Laboratory at Kansas State University and the Central Appalachian Stable 304 Isotope Facility at the University of Maryland following standard procedures for

305 sediment samples. In-house standards calibrated to PeeDee Belemnite $\left(\delta^{13} \mathrm{C}\right)$ and 306 atmospheric $\mathrm{N}_{2}$ gas $\left(\delta^{15} \mathrm{~N}\right)$ were utilised. Analytical error was better than $0.1 \%$ for $\delta^{13} \mathrm{C}$ 307 and better than $0.2 \%$ for $\delta^{15} \mathrm{~N}$. C:N ratio of the bulk sediment was calculated by 308 dividing $\% \mathrm{C}$ by $\% \mathrm{~N}$.

310 In oligotrophic lakes, sedimentary $\delta^{13} \mathrm{C}$ is correlated with lake productivity due to algal 311 photosynthetic demand for dissolved carbon dioxide. Under some conditions, microbial 312 processes of organic carbon, particularly by methanogenic bacteria in anoxic conditions, 313 can leave strongly depleted organic $C$ in the sediments (extremely negative $\delta^{13} \mathrm{C}$ values; 314 Hollander and Smith. 2001). Sedimentary $\delta^{15} \mathrm{~N}$ reflects integrated terrestrial and aquatic $315 \mathrm{~N}$ cycling processes, with gaseous losses such as denitrification strongly fractionating 316 and leaving enriched $N$ in the system (McLauchlan et al. 2013b). Sedimentary C:N is 317 interpreted as reflecting the source of organic matter, because aquatic and microbial 318 organic matter has a characteristic $\mathrm{C}: \mathrm{N}$ of 10 , while the $\mathrm{C}: \mathrm{N}$ of terrestrial material is 319 higher than 10 due to the structural C compounds in higher plants (Meyers. 1994; 320 Kaushal and Binford 1999). 


\section{4. Results}

\section{4.1. Sediment description}

325 The $10.40 \mathrm{~m}$ core was divided into six basic sedimentary units on the basis of mineralogy,

326 biotic components seen from smear slides, and general sediment appearance and

327 composition (Fig. 3). Sediment characteristics indicate a variety of large changes in

328 redox conditions, clastic and biogenic sources of sediment, and mineral composition

329 over the entire record. The six lithological units are numbered sequentially from the top

330 of the core (most recent sediments) to the bottom of the core (oldest sediments): Unit 1

331 (top of core, 0-21 cm) consists of organic and diatomaceous-rich sapropels with pyrite

332 framboids; Unit $2(21-384 \mathrm{~cm})$ consists of organic and diatomaceous-rich sapropels; Unit

$3333(385-682 \mathrm{~cm})$ consists of laminated and banded organic and diatomaceous sapropels

334 with vivianite (hydrated iron phosphate) disappearing halfway in the section and

335 diatoms appearing around the same time; Unit $4(682-712 \mathrm{~cm})$ consists of large black

336 bands; Unit $5(712-943 \mathrm{~cm})$ consists of massive vivianite-rich clayey silt; and Unit 6 (943

$337 \mathrm{~cm}$ to bottom of core) consists of clay and silt-sized quartz with large amounts of

338 opaque particles (likely pyrite, ferrihydrite and hematite). Turbidite layers are present in

339 Unit 6.

341 The RGB colour values demonstrate a strong relationship between the colour of the 342 sediment and the total organic carbon (TOC) present (Fig. 3). The grey to dark brown

343 transition occurs gradually from c. 748 to $691 \mathrm{~cm}$ (middle of Unit 5 to top of Unit 4) and

344 is seen in the RGB colour data. The general trajectory of change is a reduction in RGB

345 values from the basal sediments $(>48)$ to the surface-water interface $(<15)$. Within this

346 general trend two marked features are apparent: i) the large dramatic decline in RGB

347 values from $\sim 40$ at $748 \mathrm{~cm}(17,200 \mathrm{cal} \mathrm{yr} \mathrm{BP})$ to 22 by $691 \mathrm{~cm}(13,000 \mathrm{cal} \mathrm{yr} \mathrm{BP})$, and ii)

348 a further sharp decline in RGB values in sediments deposited above $4 \mathrm{~cm}$. 
350 Thin laminae are clearly visible in several portions of the core, which in some sections of

351 the sedimentary sequence could represent varves (annual laminations) either due to

352 seasonal biological activity or seasonal physical dynamics such as glacial meltwater

353 patterns.

354

355 4.2. Sediment deposition and chronology

356 Six ${ }^{14} \mathrm{C}$ AMS dates were used to establish the core chronology for the 2012 Devils Lake

357 core (Table 1). The model reveals a mean sedimentation rate of 23.4 years $/ \mathrm{cm}$ from 0 to

$358769 \mathrm{~cm}$ (Fig. 3). The highest and most consistent sedimentation rates $(19.3 \mathrm{yr} / \mathrm{cm})$

359 occurred from $701 \mathrm{~cm}$ depth to the surface water interface $(14,100$ cal yr BP to modern).

360 This value is consistent with those rates calculated from the previous core, which

361 averaged $22.3 \mathrm{yr} / \mathrm{cm}$ between 633 and $0 \mathrm{~cm}$ depth (14,100 cal yr BP to modern) (Maher

362 1982). The difference in rates can be accounted for by the location of 2012 core and

363 effect of sediment focusing in this deeper portion of the lake. In the 2012 core, an

364 average sedimentation rate of $74.6 \mathrm{yr} / \mathrm{cm}$ is seen from 769 to $701 \mathrm{~cm}(18,500$ to 13,400

365 cal yr BP).

366

367 There is considerable uncertainty about the age of material below 18,500 cal yr BP (769

$368 \mathrm{~cm}$ ), but if the age model is extended with the average sedimentation rate for the core,

369 the oldest material could be as old as c. 28,000 cal yr BP. This would be the oldest

370 lacustrine sedimentary material discovered in this region by approximately 14,000 years.

371 Several lines of evidence indicate that the lowest core material was deposited in a

372 sedimentary sequence and not significantly reworked or altered by the complicated

373 glacial dynamics of this region: i) the high-resolution magnetic susceptibility

374 measurements $(\kappa)$ show a strong cyclical stratigraphic pattern for the lower portion of

375 the core (Fig. 5), and ii) the lithology exhibits laminations and banding in a stratigraphic

376 manner in the lower portions of the core.

377

378

\subsection{Charcoal}


380 The oldest sediments are characterised by the lowest total charcoal abundances

381 observed within the entire record (<14 particles $\mathrm{cm}^{-3}$; mean $=1.8$ particles $\mathrm{cm}^{-3}$; Fig. 4).

382 These sediments consist of 299 samples analysed between the base of the core and $c$.

$38317,000 \mathrm{cal}$ yr BP (1040 and $741.5 \mathrm{~cm})$ with $17.7 \%$ of these samples containing no

384 charcoal particles. The ratio of non-arboreal to total charcoal was low during this period

385 (mean $=0.3 ;$ Fig.4). A notable exception to this generally low ratio is seen in a short

386 period of higher values occurring between 820 to $842 \mathrm{~cm}$ (mean =1.4, c. 20,300 to

$38721,000 \mathrm{cal}$ yr BP). In total $95 \%$ of all charcoal particles were identified as being from an

388 arboreal source. Although these sediments have very low charcoal counts, CHAR

389 analysis suggests a small peak (magnitude $=5)$ at 18,840 cal yr BP $(778.5 \mathrm{~cm}$ )

391 The number of charcoal particles abruptly increased at $c .17,000 \mathrm{cal}$ yr BP $(741.5 \mathrm{~cm})$

392 and remained high until c. 11,600 cal yr BP $(642.5 \mathrm{~cm})$. The 98 sediment samples

393 analysed during this time period had a mean of 108.6 particles $\mathrm{cm}^{-3}$. In addition, there

394 was a shift in the ratio of non-arboreal to total charcoal to a mean of 0.14 ,

395 corresponding to an $83 \%$ contribution of charcoal particles from arboreal sources. CHAR

396 analysis indicates 14 fire peaks with magnitudes of 5-162.

398 From c. 11,600 to c. 10,000 cal yr BP $(642.5$ to $581.5 \mathrm{~cm})$ charcoal abundance and fire 399 frequency gradually decreased. Total charcoal count averaged 53.4 particle $\mathrm{cm}^{-3}$. This 400 period includes the Younger Dryas (YD) chronozone, regionally characterised by cool 401 and dry conditions, so we assume that the overall reduction in fire activity is a climatic 402 response. Fuel sources shifted to finer fuels, as indicated by a slightly higher proportion 403 of non-arboreal to total charcoal particles during this period (mean $=0.25$ ) compared to 404 previous samples. CHAR analysis indicates 9 fire peaks during this timeframe with 405 magnitudes $<20$. Notably, this period is punctuated by an initial short peak in total 406 charcoal counts ( $\max 125$; mean 84.6 particles $\mathrm{cm}^{-3}$ ). 407 
408 After c. 10,000 cal yr BP $(581.5 \mathrm{~cm})$ fire activity increased with mean total charcoal 409 counts of 135.8 particles $\mathrm{cm}^{-3}$ until c. 5,500 cal yr BP $(357.5 \mathrm{~cm})$. Despite this overall 410 increase in fire activity, the ratio of non-arboreal to total charcoal remained at similar

411 level to the previous period (mean of 0.26 ) with $71 \%$ of all charcoal particles from

412 arboreal sources. However, there is considerable variability in the fuel source

413 fluctuations during this period, with the ratio of non-arboreal to total charcoal pieces

414 ranging from 0 to 0.61 . Fourteen fire peaks are suggested by CHAR analysis with

415 magnitudes from 17 to 340. This period corresponds with a time of high abundance of

416 pollen from hardwood tree species such as Acer, Ostrya/Carpinus, and Ulmus (see

417 below).

418

419 A dramatic reduction in fire activity is evident between c. 5,500 and c. 420 cal yr BP

420 (357.5 $-19.5 \mathrm{~cm}$; mean total charcoal $=19.6$ particles $\left.\mathrm{cm}^{-3}\right)$. During this period of overall

421 reduction in fire intensity, non-arboreal fuel sources contribute a significant volume,

422 with several distinct fire events (e.g. 4542, 4378 and 784 cal yr BP) comprised of 100\%

423 non-arboreal charcoal particles. CHAR analysis suggests that the overall peak magnitude

424 of this timeframe is low. However, 6 peak events are identified with magnitudes 24-61.

425

426 The uppermost sediments exhibited another sudden increase in the total number of

427 charcoal particles at c. 420 cal yr BP $(19.5 \mathrm{~cm})$. This transition aligns precisely with the

428 lithological transition to Unit 1. The mean charcoal counts for the 20 samples in this

429 period are 92.3 particles $\mathrm{cm}^{-3}$, with all samples containing $>11$ particles $\mathrm{cm}^{-3}$. The ratio

430 of non-arboreal to total charcoal is once again low (mean $=0.04$ ), with over $88 \%$ of all

431 charcoal particles being from arboreal sources. CHAR analysis indicates a fire peak at

432375 cal yr BP with an extremely high peak magnitude (155). Background CHAR gradually

433 increases to the present day.

434

435 4.4. Pollen

436 
437 The pollen stratigraphy follows some of the same features as the charcoal data, with

438 some key differences (Fig. 4). Three of the new pollen samples from the 2012 core,

439 those below $750 \mathrm{~cm}$, indicate low pollen influx and poor pollen preservation during this

440 section. This is seen as degraded and oxidized grains as well as high spore

441 concentrations relative to pollen concentrations. Below $750 \mathrm{~cm}$, pollen concentrations

442 are all below 15,000 grains/cc sediment. The basal pollen assemblage at $1034 \mathrm{~cm}$ has

443 significantly lower percentages of Picea pollen (15\%) and higher percentages of Poaceae

$444 \quad(38 \%)$ and Artemisia (9\%) than samples in the younger part of the core that date to the

445 maximum glacial extent at $18,500 \mathrm{cal} \mathrm{yr} \mathrm{BP.} \mathrm{The} \mathrm{new} \mathrm{pollen} \mathrm{samples} \mathrm{indicate} \mathrm{that} \mathrm{Picea}$

446 was a significant component on the landscape for several thousand years prior to

44711,500 cal yr BP. Picea pollen percentages reached $60 \%$ by at least $18,500 \mathrm{cal}$ yr BP,

448 although its actual vegetation cover is unclear from pollen assemblage data alone.

450 No obvious stratigraphic change in pollen assemblages is evident at c. 17,000 cal yr BP

451 when fires began occurring on the landscape, but the vegetation type appears to have

452 been similar to spruce forest, spruce parkland or tundra due to high percentages of

453 Picea pollen (over 50\%) as well as Poaceae and Artemisia pollen types (over 25\%). A

454 relatively stable vegetation composition existed at this time, with some minimal

455 adjustment in the relative proportion of Picea on the landscape, as documented in

456 pollen assemblage ( 45 to $60 \%$ ).

458 The pre-Holocene pollen record suggests a slight shift in vegetation composition as

459 documented by a sharp and brief (300 year) decline in Picea pollen (to $<18 \% ; 588 \mathrm{~cm}$ )

460 that is concomitant with the onset of the YD chronozone (12,900 cal yr BP). Fraxinus

461 pollen also exhibits markedly reduced levels $(<10 \%)$ during a portion of the YD

462 chronozone, between 12,500 and 11,400 cal yr BP.

463

464 The remainder of the Holocene pollen record has been described in great detail 465 elsewhere, but we describe a few of the main features here. Some of the classic 
466 successional tree genera-Populus and Betula-began to increase during or

467 immediately after the YD chronozone. Populus pollen types are first recorded in

468 significant abundance (>15\%) from c. 13,400 cal yr BP, and Betula pollen types are

469 recorded ( $>10 \%$ pollen) from 12,000 cal yr BP. These genera reached their maxima for

470 the sedimentary record at 12,600 and 10,900 cal yr BP (30 and $25 \%$ ) respectively. The

471 main feature of the early- to mid-Holocene pollen record is the relatively high

472 percentage abundances of hardwood taxa (i.e. Acer, Carya, Ostrya, and Ulmus)

473 documented between c. 10,500 and c. 5,500 cal yr BP. During this period these

474 hardwood taxa accounted for between $41-19 \%$ (mean $=28 \%$ ) of all pollen recorded.

475 Following the decline of the hardwood forest pollen abundance at c. 5,500 cal yr BP,

476 herbaceous pollen types doubled in average abundance to $11 \%$ of the total pollen sum

477 and remained stable until c. 420 cal yr BP. Quercus pollen percentages remained high

478 (mean 48\%), reaching a maximum of $60 \%$ at $3,350 \mathrm{cal} y r$ BP. The uppermost sediments

479 feature a distinctive pollen assemblage, most notably expressed by an abrupt increase in

480 the concentration of Ambrosia pollen (>30\%) from c. 420 cal yr BP. These uppermost

481 sediments also document the lowest percentage abundance of Pinus pollen for over

48211,000 years.

483

484 4.5. Magnetic parameters and measurements

485 From the base of the core $(1040 \mathrm{~cm})$ to c. $26,000 \mathrm{cal}$ yr BP $(1000 \mathrm{~cm})$, magnetic 486 susceptibility $(\kappa)$ showed high frequency and high amplitude variation ( $\min =38.610^{-5} \mathrm{SI}$, $487 \max =65.210^{-5} \mathrm{SI}$ ) around a mean of $56.310^{-5}$ (Fig. 5). Magnetic susceptibility values then 488 steadily increased to a maximum of $95.210^{-5} \mathrm{SI}$ at c. $24,000 \mathrm{cal}$ yr BP $(936 \mathrm{~cm})$. After 489 reaching the highest values recorded in the entire record, $\kappa$ values declined until 16,000 490 cal yr BP in a cyclical saw-toothed pattern with four peaks (at $849 \mathrm{~cm}, 804 \mathrm{~cm}, 17,600$ $491 \mathrm{cal} y \mathrm{r} \mathrm{BP}$ and 16,600 cal yr BP). A final distinct peak is recorded in $\kappa$ values of $35.8 \mathrm{SI} 10^{-5}$ 492 at $14,700 \mathrm{cal} y \mathrm{r} \mathrm{BP}$. $\square$ gradual decline in $\kappa$ is observed for the remainder of the record 493 with two notable exceptions: i) a small increase to $5.9 \mathrm{SI} 10^{-5}$ at c. 7,600 cal yr BP (480 $494 \mathrm{~cm})$, and ii) a larger spike to $18.4 \mathrm{SI} 10^{-5}$ at $c .120 \mathrm{cal}$ yr BP $(8 \mathrm{~cm})$ in the uppermost 
495 sediments. $M_{s}$ and IRM show similar trends, albeit at lower resolution. High values or

496 these concentration-dependent parameters are consistent with sustained input of

497 material of glacial origin. The decline in ARM values is much less prominent, signifying

498 that this parameter is not controlled entirely by lithogenic input, but is sensitive to input

499 of finer material from either the terrestrial of aquatic systems.

500

501 The ratio $\chi_{\text {ARM }} / \mathrm{IRM}$ ratio documents low values $(<0.2 \mathrm{~mm} / \mathrm{A})$ and little variability prior to

502 c. 12,800 cal yr BP, reflecting an extremely low proportion of fine-grained magnetite (Fig.

503 5). A marked increase in $\chi_{\text {ARM }} /$ IRM occurred c. 12,800 cal yr BP, concomitant with a

504 change in lithology at the onset of the YD chronozone. This postdates the establishment

505 of terrestrial vegetation and onset of fire. After 12,800 cal yr BP, $\chi_{\text {ARM }} /$ IRM steadily

506 increased to $0.8 \mathrm{~mm} / \mathrm{A}$ by 7,300 cal yr BP, before declining to $0.3 \mathrm{~mm} / \mathrm{A}$ by $4,800 \mathrm{cal} \mathrm{yr}$

507 BP and remaining below 0.6 until 2,400 cal yr BP. A marked increase occurred at this

508 point (> $1 \mathrm{~mm} / \mathrm{A}$ ) before a sudden and brief maximum value at $140 \mathrm{cal} \mathrm{yr}$ BP $(1.5 \mathrm{~mm} / \mathrm{A})$.

509 A reduction in $\chi_{\text {ARM }} /$ IRM during the EuroAmerican settlement period at the top of the

510 core occurs after this maximum. The $M_{r s} / M_{s}$ ratio documents similar fluctuations to

$511 \chi_{\text {ARM }} /$ IRM, except for the first part of the record $(>16,000$ cal yr BP), where it exhibits

512 more variability, including a significant peak at 17,000 cal yr BP.

513

514 The component analysis of the ferrimagnetic fraction indicates that the predominant

515 magnetic fraction (represented by the LITH and PED end members) is detrital, eroded

516 from catchment soils and bedrock (Fig. 5). The dominant component is LITH, with a

517 mass fraction $>0.5$ of the magnetic material for most the entire length of the sediment

518 core. Magnetic concentration was highest and grain size largest during the glacial period,

519 typical of increased erosion in the catchment and potentially also input from nearby

520 glacial lakes which occupied the Stienke and Feltz basin (Attig et al. 2011). The most

521 notable pre-Holocene event in the magnetic record occurred at c. 17,000 cal yr BP.

522 Synchronous with the onset of fire, a sharp increase in PED and reduction in LITH 
523 fractions occur. These magnetic changes are consistent with pedogenic magnetite from

524 the catchment soils being transferred to the lake after fire events.

525

526 Throughout much of the Holocene magnetic concentration generally remained constant,

527 as illustrated by $\mathrm{M}_{\mathrm{s}}, \mathrm{IRM}$, and $\mathrm{\kappa}$. The proportion of magnetosomes originating from

528 magnetotactic bacteria (represented by the BIO end member) increased after

529 deglaciation (17,500 cal yr BP) as detrital flux decreased and biological productivity

530 increased, and then more markedly at $11,00 \mathrm{cal}$ yr BP. During the mid-Holocene the BIO

531 fraction decreased due to sustained detrital fluxes possibly of aeolian origin

532 (McLauchlan et al., 2013a). At 2,400 cal yr BP, a sudden increase in the fraction of BIO

533 occurred, which is linked to a reduced influx of detrital grains. Magnetic grain size and

534 concentration increased again in the most recent part of the record, likely due to

535 anthropogenic influence in the region including agriculture-related erosion.

\section{4.6. Carbon and nitrogen measurements}

539 Organic matter concentration of the basal sediments was extremely low, indicating very

540 low or no deposition of organic material. The most obvious stratigraphic change in the

541 organic geochemical record is a regular and prolonged increase in sedimentary organic

542 matter concentration that began c. 17,000 cal yr BP and continued until c. 12,000 cal yr

543 BP (Fig. 6). During this 5,000 year period, nitrogen (N) concentration increased from

5440.14 to $0.84 \%$ and carbon (C) concentration increased from 0.8 to $8.9 \%$. This sudden

545 increase in organic matter close to the beginning of ecosystem development was

546 suggested by other proxies such as spectral analysis and lithology.

547

548 This organic matter could be derived from increases in terrestrial primary productivity,

549 lacustrine productivity, or both. There is a clear shift from aquatic or microbial to

550 terrestrial sources of organic matter in the record supported by the $\mathrm{C}$ and $\mathrm{N}$ data.

551 Sedimentary C:N ratios change from $\sim 5$ in basal sediment to $>10$ by 12,000 cal yr BP. The 
552 increase in bulk $\mathrm{C}: \mathrm{N}$ to a ratio greater than 10 must reflect at least some organic matter

553 contribution from increased terrestrial primary productivity. The contribution of aquatic

554 productivity is more difficult to discern as the interpretation of sedimentary $\delta^{13} \mathrm{C}$ cannot

555 simply be correlated with lake productivity, due to extremely negative values (<-26\%).

556 Sedimentary $\delta^{13} \mathrm{C}$ was actually declining at the same time as the increases in organic

557 matter concentrations of both $\mathrm{C}$ and $\mathrm{N}$, likely indicating increased anoxia due to the

558 deep lake level, relative lack of mixing, and formation of Devils Lake as an isolated basin.

559 The lowest values of sedimentary $\delta^{13} \mathrm{C}$ correspond with the black banding in lithological

560 Unit 4 due to reduced iron (14,300 to $12,800 \mathrm{cal}$ yr BP). The trajectory of increasing C

561 and $\mathrm{N}$ concentrations seems not to have been affected by this period of anoxia.

562

563 Bulk sedimentary $\delta^{15} \mathrm{~N}$ does not demonstrate much variation across the 17,000 to

$56412,000 \mathrm{cal}$ yr BP transition zone with the other geochemical proxies, rather continuing to

565 exhibit similar temporal dynamics from the late-Pleistocene towards the Holocene

566 transition. Bulk sedimentary $\delta^{15} \mathrm{~N}$ integrates a variety of nutrient cycling processes in

567 terrestrial and aquatic habitats, often predominantly reflecting loss of inorganic $N$ to the

568 atmosphere through denitrification. The redox conditions and nutrient status of the lake

569 seem to be dynamic but were not directionally changing during most of the sedimentary

570 record.

571

572 A period of slightly elevated $\delta^{15} \mathrm{~N}$ exists from 12,700 to 5,600 cal yr BP,

573 contemporaneous with lithological Unit 3 . While the timing of more recent decline in

$574 \delta^{15} \mathrm{~N}$ of this period can be closely associated with the decrease in hardwood taxa and

575 total charcoal count (see above) as well as the lithological transition from Unit 3 to Unit

5762 , the increase is only loosely linked to changes in pollen assemblage (i.e. Ulmus and

577 Betula). There is one additional geochemical change during the Holocene: a reduction in

578 OM concentration (both \%C and \%N), a decline in $\mathrm{C}: \mathrm{N}$, and a decline in $\delta^{15} \mathrm{~N}$ around

5797,500 cal yr BP. A sudden decline in sedimentary $\delta^{15} \mathrm{~N}$ at the top of the core around after

$580130 \mathrm{cal}$ yr BP $(8 \mathrm{~cm})$ is likely due to agricultural transformation of the region. Reductions 
581 in $\% \mathrm{C}$ and $\% \mathrm{~N}$ predate this decline in $\delta^{15} \mathrm{~N}$ (by 200 years) but strongly indicate increased

582 clastic input during this time period, consistent with erosional inputs from increased

583 agriculture.

584

585 5. Discussion

586

\subsection{Reconstruction of environments from pre-glacial maximum}

The oldest portion of the sedimentary record $(>18,500 \mathrm{cal}$ yr BP) is in some ways

589 the most intriguing, as regional lacustrine sedimentary records of this duration are

590 extremely scarce. Although the precise chronology remains unknown, the basal

591 sediments of Devils Lake could be 28,000 years old, which would revolutionise the

592 temporal resolution of glacial dynamics in this region. Recent work suggests that

593 regional lake formation could have been underway at this time (Carson et al. 2012). We

594 do know that the ice sheet was very close to the site during much of this time period

595 (within tens of $\mathrm{km}$ ) and must have been adjacent to the lake at the time of terminal

596 moraine formation, and thus maximum ice sheet extent (Attig et al. 2011). During this

597 time there was virtually no organic matter input to lake (either terrestrial or aquatic), as

598 documented by the extremely low sedimentary \%C and RGB values. Interpretation of

599 the vegetation at this time is not straightforward: the pollen percentages alone indicate

600 a spruce tundra but the low concentrations and poor pollen preservation indicate the

601 potential for a tundra with only a few sparse trees or some bare soil surface with little

602 vegetation cover. An increasing number of cryptic refugia have recently been discovered

603 in high latitude locations thought to have been ice-covered or otherwise climatically

604 unsuitable for vegetation growth, including Europe (Parducci et al. 2012) and North

605 America (Petit et al. 2008). The spruce pollen in the Devils Lake record during pre-glacial

606 maximum times may indicate spruce trees growing closer to the glacial margin of the

607 Laurentide Ice sheet than previously supposed, perhaps on the highlands either side of

608 the current lake basin. There is one continuous and well-dated pollen record from this

609 time period, approximately $550 \mathrm{~km}$ to the south of Devils Lake (at Pittsburg Basin in 
610 central Illinois), and it contains records of several recurrences of Pinus and Picea forests

611 during glacial times (Teed 2000). In addition, there is also evidence from small plant and

612 insect macrofossils assemblages for tundra-like conditions with scattered Pinus and

613 Picea at the full glacial (Baker et al. 1989; 1999)

615 The relative vegetation stability (Picea pollen percentages of 45 to $60 \%$ ) occurred

616 during one of the most dynamic portions of the entire record regarding climatic and

617 geomorphological change, and therefore does not support the idea of a primary

618 successional sequence, even a very slow one that took place over a timeframe of 2,000

619 years. There is not much evidence for primary succession that was hypothesised to

620 occur in the region as a blank landscape was colonised first by tundra vegetation, then

621 spruce trees.

622 Whatever the vegetation composition at Devils Lake during the early postglacial

623 period, there were no fires on the landscape at this time. To our knowledge, there are

624 no other charcoal records from this time period and region, making this site an

625 important data point indicating lack of fire at this time for regional and global fire

626 reconstructions (Power et al. 2010; Marlon et al. 2009). The charcoal record from

627 Pittsburgh Basin indicates relatively low fire frequency during glacial times, despite the

628 presence of glacial Picea forests (Teed 2000). The magnetic parameters at Devils Lake

629 indicate high erosion rates supplying significant amounts of clastic material to the lake,

630 but sedimentation rate is difficult to estimate due to the chronological uncertainty in

631 this section of the core. This material is derived from either glacial-periglacial

632 environments or soils, and was likely transported to the lake via riverine, meltwater, or

633 aeolian pathways. The apparent cyclicity in the $\kappa$ data hints at a possible link with

634 climate records from oxygen isotopes preserved in speleothems from lowa and Missouri

635 (Dorale et al. 2010). However, it is likely that these sedimentary magnetic fluctuations

636 reflect more local climatic controls or localised ice sheet dynamics (marginal collapses,

637 melt water release events), as they do not precisely match dynamics seen in the

638 Greenland ice cores (Blaauw et al. 2010). 


\subsection{Biotic and abiotic interactions during ecosystem development}

While the timing of local ice sheet maximum extent is difficult to determine

643 without large dating errors, the glacial ice at the Devils Lake site had begun to thin and

644 retreat at c. 18,500 cal yr BP (Attig et al. 2011, Carson et al. 2012). The sedimentary

645 succession at Devils Lake uniquely records several key events which occurred during and

646 after this retreat, although somewhat asynchronously.

647 The abrupt onset of fire at 17,000 cal yr BP is a strong feature of the Devils Lake

648 record that is not currently associated with a known mechanism. The onset of fire

649 cannot be associated with an obvious vegetation change, as pollen assemblages indicate

650 the presence of a spruce tundra or forest both immediately before and after 17,000 cal

651 yr BP. Sites several hundred kilometers to the south indicate more productive spruce

652 forest than likely existed at Devils Lake, but a similar abrupt onset of fire. A fire regime

653 initiated c. 10,500 cal yr BP (in Indiana) and c. 15,500 cal yr BP (in Ohio) when charcoal

654 morphotypes indicate woody fuel sources (Gill et al. 2009, Gill et al. 2012). Whatever

655 the trigger for the onset of fire at Devils Lake, the impact was a brief period of high

656 transfer of soil-derived particles, as evidenced by the magnetic component PED.

657 The second main change in ecosystem development was the start of an increase

658 in organic matter concentration within the lake sediments that also began at c.17,000

659 cal yr BP. This steady increase in organic matter occurred over a 5000 year period

660 between c. 17,000 cal yr BP and c. 12,000 cal yr BP. Other sites, such as a high-altitude

661 mountain lake in Switzerland (Thevenon et al. 2012), do not exhibit such a clear and

662 prolonged rate of organic matter accumulation. Although large changes in fire and

663 organic matter input early in ecosystem development are indications of strong biotic

664 control, there is also evidence that some aspects of ecosystem development were

665 strongly abiotically controlled, specifically lake processes and productivity. In particular,

666 there was a hypothesised anoxic period in lithologic Unit 4 (c. 14,300 - c. 12,800 cal yr

667 BP) due to the presence of cold, deep, stratified lake water. 


\section{2.b. Younger Dryas}

670 The YD chronozone (12,800-11,500 cal yr BP) can be thought of as a climate 671 perturbation to the trajectory of ecosystem development. This period was cool and dry 672 in the region, which seems to be supported with well-dated synoptic studies (Shuman et 673 al. 2002, Grimm et al. 2009). At Devils Lake the main expression of the YD was a brief 674 decline in Picea pollen and a concomitant increase in Populus pollen percentages. There 675 was a slight reduction in fire activity possibly due to increased aridity. Brief droughts 676 have affected fire activity in spruce forests and tundra in Alaskan ecosystems (Hu et al. 677 2010). Arid conditions have been demonstrated throughout the midcontinent during 678 the YD, with steep environmental gradients ranging from a C4-rich prairie in 679 southwestern Missouri to spruce forests in lowa, Illinois, and Ohio (Dorale et al. 2010) as 680 well as the Devils Lake site farther to the north.

681 Although the terrestrial ecosystem had been functioning for several thousand 682 years, at least with some vegetation on the landscape, aquatic productivity did not 683 become significant until 12,800 cal yr BP when anoxic conditions ceased at the 684 beginning of the YD-this is seen as an increase in $\delta^{13} \mathrm{C}$ values, an increase in organic 685 matter $\mathrm{C}: \mathrm{N}$, and the first appearance of diatoms in the sediment core. All of these 686 proxies taken together indicate increased algal productivity. This increase in productivity 687 may have been triggered by a combination of climate change, the lake becoming 688 shallow and more mixed, and permafrost conditions lasting after deglaciation. However, 689 despite this one significant ecosystem shift during the YD, this site is really not the 690 strongest expression of the YD chronozone. What is apparent is that no single proxy 691 adequately brackets the YD chronozone, with some responding during the onset, others 692 adjusting at the termination, and many demonstrating no shift whatsoever. 693

\section{2.c. Holocene}

The main change during the Holocene was an increase in fire activity for a 6,000 year period of hardwood forest (c.11,000 to 5,000 cal yr BP). This is a rare type of fire 
697 regime for this vegetation structure, because modern hardwood forests often exhibit no 698 fire occurrence (Nowacki and Abrams 2008); therefore the potential fire regimes of

699 hardwood forests have not received much attention in sedimentary palaeorecords.

700 Although hardwood forest fire regimes are not well-understood, fire reconstructions of

701 hardwood forests in central Minnesota indicate there has been significant charcoal

702 influx from past hardwood forests primarily consisting of Acer, Ostrya-Carpinus, Ulmus

703 and other hardwood tree species, suggesting that ground fires were more common than

704 assumed (Umbanhowar 2004). The increases in fire frequency and possibly severity

705 during the hardwood period at Devils Lake appear to be driven by climate and mediated

706 through changes in vegetation composition and structure. There are also unanswered

707 questions about the degree of regional synchrony in fire regimes (Marlon et al. 2009),

708 with sites in Quercus-dominated forests to the east demonstrating highly individualistic

709 fire patterns throughout the Holocene (Mueller 2014).

$710 \quad$ Nutrient cycling appears to have been dynamic throughout the Holocene but did

711 not demonstrate much or any directional change over time. If we assume that the mid-

712 Holocene was warm at this site, as interpreted by the original analysts (Baker et al.

713 1992), there should be some ecosystem-level consequences of this warming. A study of

71420 lakes to the west in Minnesota indicated that climate change during the past $\sim 1000$

715 years did have regional effects on lake ecosystems (some with hardwood-forested

716 catchments) including changes in sedimentary $\mathrm{C}: \mathrm{N}$, organic matter concentration, and

$717 \quad \delta^{15} \mathrm{~N}$ with warming, but that among-lake variability was high, reflecting the importance

718 of local factors (Umbanhowar et al. 2011). This confirms the idea that the lake is filtering

719 environmental changes in the catchment (Olsen et al. 2013). In any case, there does not

720 seem to be a strong case for expression of the mid-Holocene Warm Period in pollen,

721 charcoal, or other proxies.

722 One notable change during the mid-Holocene at Devils Lake was the lithological

723 change at c. 6,000 cal yr BP. This change is associated with a decline in $\delta^{15} \mathrm{~N}$, decline in

724 hardwood pollen types, decline in total charcoal, and a slight increase in non-arboreal

725 charcoal morphotypes. It is also approximately timed with a decline in the proportion of 
$726 \mathrm{BIO}$ and an increase in the LITH fraction. Prior to this point, sedimentary $\delta^{15} \mathrm{~N}$ seemed

727 unaffected by changes in terrestrial ecosystem processes such as pollen and charcoal.

728 After this point, sedimentary $\delta^{15} \mathrm{~N}$ seems linked with these proxies, indicating a switch in 729 control.

$730 \quad$ Magnetic concentration-dependent parameters $\left(\kappa, I R M, M_{s}\right)$ indicate a steady

731 decline in the mass fraction of ferrimagnetic material, which decreases by more than an

732 order of magnitude from the LGM to the beginning of the Holocene, after which the

733 concentration remains relatively constant except for very recent times. The decline in

734 several magnetic parameters, including $C_{\text {ferri, }}, \chi, \kappa$, and $M_{s}$, indicates reduced terrestrial

735 input over time and may be a consequence of landscape stabilisation. A gradual

736 reduction in terrestrial inputs over the history of ecosystem development was also seen

737 in Deming Lake, Minnesota (McLauchlan et al. 2013a). This trajectory of gradual

738 dystrophication has been proposed as a consequence of reduced material flux over time

739 (Leavitt et al. 2009) and has also been seen in an oligotrophic lake in Scotland (Oldfield

740 et al. 2010). There was a reduction in the fraction of BIO from c. 5,000 to 3,000 cal yr BP,

741 then an increase to the highest levels in the record, corresponding to the most

742 eutrophic conditions observed in the record, just prior to the period of strong

743 anthropogenic influence. This increase in the proportion of magnetosomes after 3,000

744 cal yr BP may indicate either reduced erosion rates in the catchment, or high rates of

745 magnetosome production in the lake. The increase in ARM values and $\% \mathrm{~N}$ at the same

746 time supports the latter scenario, suggesting an increase in nutrient delivery to the lake

747 water during a period of warm/humid climatic conditions.

\section{2.d Post Euro-America Period}

750 The final step of ecosystem development at this site involves the recent imprint

751 of anthropogenic activities. The Devils Lake sediment core, like many other sites,

752 records a set of commonly-observed changes seen in the Midwestern region due to

753 Euro-American settlement and land use change beginning in the $19^{\text {th }}$ century. Along

754 with the ubiquitous Ambrosia rise and increase in fire activity seen in much of North 
755 America (Foster et al. 1998), there are clear increases in sedimentary input reflected in

756 lithological change and magnetic parameters. There is a decline in organic matter

757 concentrations with increased clastic inputs due to increased erosion, and an abrupt

758 decline in sedimentary $\delta^{15} \mathrm{~N}$. The decline in sedimentary $\delta^{15} \mathrm{~N}$ has been observed in

759 several, but not all, sediment cores from North America and is generally attributed to

760 increased fertiliser input although other mechanisms are possible (Holtgrieve et al.

761 2011). Interestingly, the magnitude of the modern anthropogenic changes is not as large

762 as some of the earlier changes, which contradicts many records of geochemical and

763 ecological change where the anthropogenic period is unprecedented during the

764 Holocene (Engstrom and Rose 2013), but this maybe a reflection of more limited

765 farming in the immediate vicinity of the quartzite-rich Devils Lake landscape.

766

767 5.3. Linking palaeorecords of ecosystem development with chronosequences

768 The nutrient dynamics of these changes in ecosystem properties and landscape

769 evolution are still relatively unexplored. The sedimentary $\delta^{15} \mathrm{~N}$ record at Devils Lake

770 exhibits unexplained variation, with the intriguing possibility of a change in controls on

771 nutrient dynamics from climatic factors to terrestrial ecosystem processes at c. 6,000 cal

772 yr BP. Further investigation at higher temporal resolution would be required to test this

773 hypothesis. From modern landscapes with rocks of different ages, there are some

774 estimates of weathering rates, mineral transformations, and indications of interactions

775 between vegetation and the lithosphere (Chadwick et al. 1999, Hahm et al. 2014). Again,

776 several different absolute rates have been measured, leading to difficulties in identifying

777 drivers and generalising the processes (Walker et al. 2010). Additionally, it is difficult to

778 locate an area with enough variables under control, such that only six chronosequences

779 suitable for detailed geochemical study have been identified on Earth (Wardle et al.

780 2004). While there is great potential to further understand long-term ecosystem

781 development through further study of chronosequences (Wardle et al. 2012), we

782 suggest here a complementary approach. There is also the potential to use sedimentary

783 sequences to assess the absolute rates of these processes as well as interactions with 
784 climate changes and biotic changes observed during the Holocene. One good example

785 of this approach is a study at Lake Sägistalsee in the Bernese Alps in Switzerland which

786 investigated rates of carbonate and silicate weathering over 9,000 years of ecosystem

787 development, finding a significant influence of vegetation and human activities on these

788 processes (Koinig et al. 2003).

789

790 6. Conclusions

791 This record demonstrates two important new concepts about primary succession. First,

792 the newly-deglaciated landscape was not a blank slate for plants to colonise, rather it

793 retained the imprint of glacial dynamics that set the stage and possibly the trajectory for

794 ecosystem change at this site. Quantities of glacial meltwater, position of ice, unique

795 bedrock configuration, aeolian input, surviving vegetation, and till composition all

796 contributed to the palaeorecord at Devils Lake. Second, primary succession did not

797 consist of a series of events acting perfectly in synchrony, or even sequentially. Rather

798 several different processes were initiated at different times and at different rates,

799 driven by independent factors such as geomorphic change, climate conditions, and

800 biotic factors both in the terrestrial and aquatic system. While these could be

801 interpreted as individualistic proxy responses, it is more useful to think of these as

802 linked processes capturing different signals from the system. Further, interactions

803 between the climate and terrestrial system, and inputs from terrestrial to aquatic

804 systems, combined to produce the particular pattern of palaeoenvironmental change

805 documented at this site throughout the Holocene. While embedded in regional setting,

806 Devils Lake provides a unique and very long record of ecosystem change in upper

807 Midwest of North America.

808

809

810

811 Acknowledgments 
812 This research was funded by a NSF grant to KKM (BCS-0955225). The LacCore facility is 813 supported by NSF IF-0949962. EMM was funded by NSF REU EAR-1062775. We would

814 like to thank Louis Maher and Eric Grimm for permission to use the previously

815 established pollen data set and chronology. Kristina Brady, Colin Long and Stacey Henck

816 provided field assistance, Scott McConaghy assisted with charcoal data collection, and

817 Julie Commerford and Kyleen Kelly analysed the new pollen samples. Troy Ocheltree

818 and Robin Paulman performed the isotopic analysis. Finally, are grateful to both

819 anonymous reviewers whose insightful comments greatly improved the strength of this

820 manuscript.

821 
824 Figure 1. Location of Devils Lake, Wisconsin, USA in the Baraboo Hills region of the

825 upper Midwestern U.S. Bathymetry of Devils Lake. Coring site from 2012 is shown along

826 with the coring site from 1978 reported by Baker et al. (1993) A digital elevation model

827 of the Devils Lake catchment along with maximum extent of Green Bay Lobe of the

828 Laurentide Ice Sheet at 18.5 kya is shown (Attig et al. 2011). Contour lines at $50 \mathrm{~m}$

829 intervals.

830

831 Figure 2. Bayesian age-depth model performed with Bacon (Blaauw and Christen, 2011)

832 for the Devils Lake sediment core. The upper left panel shows the iteration history, the

833 upper middle panel shows the prior (green line) and posterior (gray area) of the

834 sediment accumulation rate $(\mathrm{yr} / \mathrm{cm})$, and the upper right panel shows the prior (green

835 line) and posterior (gray area) of the memory (1 cm autocorrelation strength). The

836 bottom panel shows the age-depth models with uncertainties. The solid red line is the

837 weighted averages of all possible chronologies. Associated uncertainties are

838 represented by the grayscale and confidence intervals (dotted black lines).

839

840 Figure 3. Details of the sediment core lithology including; spectral analysis of core colour intensities (mean RGB values), the stratigraphy of the six identified units (see main text for description) and a composite image of the entire sediment core. Depths of radiocarbon dates marked $(*)$. Images of smear slides from five of the six lithological units are also shown; Unit 1, organic and diatomaceous-rich sapropels with pyrite framboids. Unit 3, diatomaceous sapropels with vivianite. Units 4 and 5, massive vivianite-rich clayey silt. Unit 6, clay and silt-sized quartz with large quantities of pyrite, ferrihydrite and hematite.

Figure 4. Terrestrial vegetation dynamics represented in pollen and charcoal from Devils Lake sediment. Red lines indicate transitions among the six lithologic units. Pollen percentages of selected pollen taxa, total charcoal counts, ratio of non-arboreal morphotype charcoal pieces: total charcoal pieces, and CHAR output indicating fire episodes per 1000 yr (crosses) and peak magnitudes (line) (Higuera et al. 2009, Higuera et al. 2010). Pollen data reported in Baker et al. (1993) are shown in colour, with new pollen samples represented as black bars. Red lines indicate transitions among the six lithologic units.

860

Figure 5. Magnetic parameters and measurements. Red lines indicate transitions among the six lithologic units. Measurements include: $\mathrm{M}_{\mathrm{s}}$ - saturation magnetization (total ferrimagentic concentration proxy), ARM - anhysteretic remanent magnetisation (sensitive to the concentration of fine-grained remanence-carrying particles), IRM isothermal remanent magnetisation (a measure of the concentration of all remanence865 plot of the biogenic, pedogenic, and lithogenic ferrimagnetic particle grain size 
866 components, calculated using a three end-member mixing model based on remanence 867 and hysteresis parameters. High resolution volume-normalised magnetic susceptibility 868 (к).

869

870 Figure 6. Organic geochemical proxies: $\% \mathrm{C}, \% \mathrm{~N}, \mathrm{C}: \mathrm{N}, \delta^{13} \mathrm{C}$, and $\delta^{15} \mathrm{~N}$. Red lines indicate 871 transitions among the six lithologic units. All samples below $9080 \mathrm{cal}$ yr BP $(550 \mathrm{~cm})$

872 were acidified to remove carbonates. 
References

Attig, J. W., P. R. Hanson, J. E. Rawling, A. R. Young, and E. C. Carson. 2011. Optical ages indicate the southwestern margin of the Green Bay Lobe in Wisconsin, USA, was at its maximum extent until about 18,500 years ago. Geomorphology 130:384390.

Baker, R.G., Rhodes II, R. S., Schwert, D. P., Ashworth, A. C., Frest, T. J., Hallberg' G. R., and Janssens' J. A. 1986, A full-glacial biota from southeastern lowa, USA. Journal of Quaternary Science 1: 91-107.

Baker, R. G., L. J. Maher, C. Chumbley, A., and K. L. Van Zant. 1992. Patterns of Holocene environmental change in the midwestern United States. Quaternary Research 37:379-389.

Baker, R. G., J. A. Mason, and L. J. Maher. 1999, Petaloid organs preserved in an arctic plant macrofossil assemblage from full-glacial sediments in southeastern Minnesota. Quaternary Research 52: 388-392.

Blaauw, M., and J. A. Christen. 2011. Flexible paleoclimate age-depth models using an autoregressive gamma process. Bayesian Analysis 6:457-474.

Blaauw, M., B. Wohlfarth, J. A. Christen, L. Ampel, D. Veres, K. A. Hughen, F. Preusser, and A. Svensson. 2010. Were last glacial climate events simultaneous between Greenland and France? A quantitative comparison using non-tuned chronologies. Journal of Quaternary Science 25:387-394.

Carson, E. C., P. R. Hanson, J. W. Attig, and A. R. Young. 2012. Numeric control on the late-glacial chronology of the southern Laurentide Ice Sheet derived from iceproximal lacustrine deposits. Quaternary Research 78:583-589.

Chadwick, O. A., L. A. Derry, P. M. Vitousek, B. J. Huebert, and L. O. Hedin. 1999. Changing sources of nutrients during four million years of ecosystem development. Nature 397:491-497.

Clayton, L., and J. W. Attig. 1990. Geology of Sauk County, Wisconsin: Wisconsin Geological and Natural History Survey Information Circular 67.

Dorale, J. A., L. A. Wozniak, E. A. Bettis, S. J. Carpenter, R. D. Mandel, E. R. Hajic, H. Lopinot, and J. H. Ray. 2010. Isotopic evidence for Younger Dryas aridity in the North American midcontinent. Geology 38:519-522.

Engstrom, D. R., S. C. Fritz, J. E. Almendinger, and S. Juggins. 2000. Chemical and biological trends during lake evolution in recently deglaciated terrain. Nature 408:161-166.

Engstrom, D. R., and N. L. Rose. 2013. A whole-basin mass-balance approach to paleolimnology. Journal of Palaeolimnology.

Finkenbinder, M. S., M. B. Abbott, M. E. Edwards, C. T. Langdon, B. A. Steinman, and B. P. Finney. 2014. A 31,000 year record of paleoenvironmental and lake-level change from Harding Lake, Alaska, USA. Quaternary Science Reviews 87:98-113.

Foster, D. R., G. Motzkin, and B. Slater. 1998. Land-use history as long-term broad-scale disturbance: regional forest dynamics in central New England. Ecosystems 1:96119. 
Gavin, D. G., F. S. Hu, K. Lertzman, and P. Corbett. 2006. Weak climatic control of standscale fire history during the late Holocene. Ecology 87:1722-1732.

Gill, J. L., J. W. Williams, S. T. Jackson, J. P. Donnelly, and G. C. Schellinger. 2012. Climatic and megaherbivory controls on late-glacial vegetation dynamics: a new, highresolution, multi-proxy record from Silver Lake, Ohio. Quaternary Science Reviews 34:66-80.

Gill, J. L., J. W. Williams, S. T. Jackson, K. B. Lininger, and G. S. Robinson. 2009. Pleistocene Megafaunal Collapse, Novel Plant Communities, and Enhanced Fire Regimes in North America. Science 326:1100-1103.

Goring, S., J.W. Williams, J.L. Blois, S.T. Jackson, C.J. Paciorek, R.K. Booth, J.R. Marlon, M. Blaauw, J.A. Christen. 2012. Deposition times in the northeastern United States during the Holocene: establishing valid priors for Bayesian age models. Quaternary Science Reviews 48:54-60.

Grimm, E. C., L. J. Maher, and D. M. Nelson. 2009. The magnitude of error in conventional bulk-sediment radiocarbon dates from central North America. Quaternary Research 72:301-308.

Hahm, W. J., C. S. Riebe, C. E. Lukens, and S. Araki. 2014. Bedrock composition regulates mountain ecosystems and landscape evolution. Proceedings of the National Academy of Sciences of the United States of America 111:3338-3343.

Harrison, R. J., and Lascu, I. FORCulator: A micromagnetic tool for simulating first-order reversal curve diagrams. Geochemistry Geophysics Geosystems. (In press).

Herrin, R. T., R. C. Lathrop, P. R. Gorski, and A. W. Andren. 1998. Hypolimnetic methylmercury and its uptake by plankton during fall destratification: A key entry point of mercury into lake food chains? Limnology and Oceanography 43:1476-1486.

Higuera, P. E., L. B. Brubaker, P. M. Anderson, F. S. Hu, and T. A. Brown. 2009. Vegetation mediated the impacts of postglacial climate change on fire regimes in the south-central Brooks Range, Alaska. Ecological Monographs 79:201-219.

Higuera, P. E., D. G. Gavin, P. J. Bartlein, and D. J. Hallett. 2010. Peak detection in sediment-charcoal records: impacts of alternative data analysis methods on firehistory interpretations. International Journal of Wildland Fire 19:669- 1014.

Hollander, D. J., and M. A. Smith. 2001. Microbially mediated carbon cycling as a control on the delta C-13 of sedimentary carbon in eutrophic Lake Mendota (USA): New models for interpreting isotopic excursions in the sedimentary record. Geochimica Et Cosmochimica Acta 65:4321-4337.

Holtgrieve, G. W., D. E. Schindler, W. O. Hobbs, P. R. Leavitt, E. J. Ward, L. Bunting, G. Chen, B. P. Finney, I. Gregory-Eaves, S. Holmgren, M. J. Lisac, P. J. Lisi, K. Nydick, L. A. Rogers, J. E. Saros, D. T. Selbie, M. D. Shapley, P. B. Walsh, and A. P. Wolfe. 2011. A Coherent Signature of Anthropogenic Nitrogen Deposition to Remote Watersheds of the Northern Hemisphere. Science 334:1545-1548.

Hu, F. S., P. E. Higuera, J. E. Walsh, W. L. Chapman, P. A. Duffy, L. B. Brubaker, and M. L. Chipman. 2010. Tundra burning in Alaska: linkages to climatic change and sea-ice retreat. Journal of Geophysical Research-Biogeosciences 115:G04002. 
Jenny, H. 1941. Factors of soil formation: a system of quantitative pedology. McGraw Hill, New York, USA.

Jensen, K., E. A. Lynch, R. Calcote, and S. C. Hotchkiss. 2007. Interpretation of charcoal morphotypes in sediments from Ferry Lake, Wisconsin, USA: do different plant fuel sources produce distinctive charcoal morphotypes? Holocene 17:907-915.

Kaushal, S., and M. W. Binford. 1999. Relationship between C:N ratios of lake sediments, organic matter sources, and historical deforestation in Lake Pleasant, Massachusetts, USA. Journal of Paleolimnology 22:439-442.

Koinig, K. A., W. Shotyk, A. F. Lotter, C. Ohlendorf, and M. Sturm. 2003. 9000 years of geochemical evolution of lithogenic major and trace elements in the sediment of an alpine lake - the role of climate, vegetation, and land-use history. Journal of Paleolimnology 30:307-320.

Leavitt, P. R., S. C. Fritz, N. J. Anderson, P. A. Baker, T. Blenckner, L. Bunting, J. Catalan, D. J. Conley, W. O. Hobbs, E. Jeppesen, A. Korhola, S. McGowan, K. Ruhland, J. A. Rusak, G. L. Simpson, N. Solovieva, and J. Werne. 2009. Paleolimnological evidence of the effects on lakes of energy and mass transfer from climate and humans. Limnology and Oceanography 54:2330-2348.

Lillie, R. A., and J. W. Mason. 1986. Historical changes in water quality and biota of Devils Lake, Sauk County 1866-1985. Transactions of the Wisconsin Academy of Sciences, Arts and Letters 74:81-104.

Long, C. J., C. Whitlock, P. J. Bartlein, and S. H. Millspaugh. 1998. A 9000-year fire history from the Oregon Coast Range, based on a high-resolution charcoal study. Canadian Journal of Forest Research 28:774-787.

Lytwyn, J. 2010. Remote sensing and GIS investigation of glacial features in the region of Devils Lake State Park, South Central Wisconsin, USA. Geomorphology 123:46-60.

Maher, L. J. 1982. The palynology of Devils Lake, Sauk County, WI. . Quaternary History of the Driftless Area. University of Wisconsin Extension, Geological and Natural History Survey, Madison, Wisconsin.

Maher, L. J., and D. M. Mickelson. 1996. Palynological and Radiocarbon Evidence for Deglaciation Events in the Green Bay Lobe, Wisconsin. Quaternary Research 46:251-259.

Marlon, J. R., P. J. Bartlein, M. K. Walsh, S. P. Harrison, K. J. Brown, M. E. Edwards, P. E. Higuera, M. J. Power, R. S. Anderson, C. Briles, A. Brunelle, C. Carcaillet, M. Daniels, F. S. Hu, M. Lavoie, C. Long, T. Minckley, P. J. H. Richard, A. C. Scott, D. S. Shafer, W. Tinner, C. E. Umbanhowar, and C. Whitlock. 2009. Wildfire responses to abrupt climate change in North America. Proceedings of the National Academy of Sciences of the United States of America 106:2519-2524.

McLauchlan, K. K., I. Lascu, A. Myrbo, and P. R. Leavitt. 2013a. Variable ecosystem response to climate change during the Holocene in northern Minnesota, USA. . Geological Society of America Bulletin 125:445-452.

McLauchlan, K. K., J. J. Williams, and D. R. Engstrom. 2013b. Nutrient cycling in the palaeorecord: Fluxes from terrestrial to aquatic ecosystems. Holocene 23:16351643. 
Meyers, P. A. (1994). Preservation of elemental and isotopic source identification of sedimentary organic matter. Chemical Geology, 114(3), 289-302.

Milner, A. M., C. L. Fastie, I. Chapin F S, D. R. Engstrom, and L. C. Sharman. 2007. Interactions and linkages among ecosystems during landscape evolution. Bioscience 57:237-247.

Mourier, B., J. Poulenard, C. Carcaillet, and D. Williamson. 2010. Soil evolution and subalpine ecosystem changes in the French Alps inferred from geochemical analysis of lacustrine sediments. Journal of Paleolimnology 44:571-587.

Moy, C. M., Seltzer, G.O., Rodbell, D.T., Anderson, D.M. 2002. Variability of El Niño/ Southern Oscillation activity at millennial timescales during the Holocene epoch. Nature 420:162-165.

Mueller, J. R., C. J. Long, J. J. Williams, A. Nurse, and K. K. McLauchlan. . 2014. The relative controls on forest fires and fuel source fluctuations in the Holocene deciduous forests of southern Wisconsin, USA. Journal of Quaternary Science 29:561-569.

Myrbo, A., Morrison, A., and McEwan, R. (2011). Tool for Microscopic Identification (TMI). http://tmi.laccore.umn.edu. Accessed on 11 November 2014

Nederbragt, A. J., R. B. Dunbar, A. T. Osborn, A. Palmer, J. W. Thurow, and T. Wagner. 2006. Sediment colour analysis from digital images and correlation with sediment composition. Pages 113-128 Geological Society, London, Special Publications.

Nowacki, G. J., and M. D. Abrams. 2008. The demise of fire and "Mesophication" of forests in the eastern United States. Bioscience 58:123-138.

Oldfield, F., R. W. Battarbee, J. F. Boyle, N. G. Cameron, B. Davis, R. P. Evershed, A. D. McGovern, V. Jones, R. Thompson, and R. Walker. 2010. Terrestrial and aquatic ecosystem responses to late Holocene climate change recorded in the sediments of Lochan Uaine, Cairngorms, Scotland. Quaternary Science Reviews 29:10401054.

Olsen, J., N. J. Anderson, and M. J. Leng. 2013. Limnological controls on stable isotope records of late-Holocene palaeoenvironment change in SW Greenland: a paired lake study. Quaternary Science Reviews 66:85-95.

Parducci, L., T. Jorgensen, M. M. Tollefsrud, E. Elverland, T. Alm, S. L. Fontana, K. D. Bennett, J. Haile, I. Matetovici, Y. Suyama, M. E. Edwards, K. Andersen, M. Rasmussen, S. Boessenkool, E. Coissac, C. Brochmann, P. Taberlet, M. HoumarkNielsen, N. K. Larsen, L. Orlando, M. T. P. Gilbert, K. H. Kjaer, I. G. Alsos, and E. Willerslev. 2012. Glacial Survival of Boreal Trees in Northern Scandinavia. Science 335:1083-1086.

Petit, R. J., F. S. Hu, and C. W. Dick. 2008. Forests of the past: A window to future changes. Science 320:1450-1452.

Power, M. J., J. R. Marlon, P. J. Bartlein, and S. P. Harrison. 2010. Fire history and the Global Charcoal Database: A new tool for hypothesis testing and data exploration. Palaeogeography Palaeoclimatology Palaeoecology 291:52-59.

Reimer, P. J., Bard, E., Bayliss, A., Beck, J.W., Blackwell, P.G., Bronk Ramsey, C., Buck, C.E., Edwards, R.L., Friedrich, M., Grootes, P.M., Guilderson, T.P., Haflidason, H., 
Hajdas, I., Hatté, C., Heaton, T.J., Hoffmann, D.L., Hogg, A.G., Hughen, K.A., Kaiser, K.F., Kromer, B., Manning, S.W., Niu, M., Reimer, R.W., Richards, D.A., Scott, M.E., Southon, J.R., Turney, C.S.M., van der Plicht, J. 2013. IntCal13 and Marine13 radiocarbon age calibration curves $0-50,000$ yr cal BP. Radiocarbon 55:18691887.

Schnurrenberger, D., J. Russell, and K. Kelts. 2003. Classification of lacustrine sediments based on sedimentary components. Journal of Paleolimnology 29:141-154.

Shuman, B., W. Thompson, P. Bartlein, and J. W. Williams. 2002. The anatomy of a climatic oscillation: vegetation change in eastern North America during the Younger Dryas chronozone. Quaternary Science Reviews 21:1777-1791.

Teed, R. 2000. A > 130,000-year-long pollen record from Pittsburg Basin, Illinois. Quaternary Research 54:264-274.

Thevenon, F., T. Adatte, J. E. Spangenberg, and F. S. Anselmetti. 2012. Elemental (C/N ratios) and isotopic (d15Norg, d13Corg) compositions of sedimentary organic matter from a high-altitude mountain lake (Meidsee, $2661 \mathrm{~m}$ a.s.l. Switzerland): Implications for Lateglacial and Holocene Alpine landscape evolution. Holocene:1-8.

Trowbridge, A. C. 1917. The History of Devils Lake, Wisconsin. Journal of Geology 25:344-372.

Umbanhowar, C. E. 2004. Interaction of fire, climate and vegetation change at a large landscape scale in the Big Woods of Minnesota, USA. Holocene 14:661-676.

Umbanhowar, C. E., P. Camill, and J. A. Dorale. 2011. Regional heterogeneity and the effects of land use and climate on 20 lakes in the big woods region of Minnesota. Journal of Paleolimnology 45:151-166.

Walker, L. R., D. A. Wardle, R. D. Bardgett, and B. D. Clarkson. 2010. The use of chronosequences in studies of ecological succession and soil development. Journal of Ecology 98:725-736.

Wardle, D. A., M. Jonsson, S. Bansal, R. D. Bardgett, M. J. Gundale, and D. B. Metcalfe. 2012. Linking vegetation change, carbon sequestration and biodiversity: insights from island ecosystems in a long-term natural experiment. Journal of Ecology 100:16-30.

Wardle, D. A., L. R. Walker, and R. D. Bardgett. 2004. Ecosystem properties and forest decline in contrasting long-term chronosequences. Science 305:509-513.

Williams, J. J., W. D. Gosling, A. L. Coe, S. J. Brooks, and P. Gulliver. 2011. Four thousand years of environmental change and human activity in the Cochabamba Basin, Bolivia. Quaternary Research 76:58-68.

Wright, H. E. J. 1967. A square-rod piston sampler for lake sediments. Journal of Sedimentary Petrology 37:975-976. 
Table 1. Radiocarbon dates and errors for sediment from Devils Lake, Wisconsin, U.S.A. Radiocarbon analyses were conducted the Center for Accelerator Mass Spectrometry (CAMS) at Lawrence Livermore National Laboratory.

\begin{tabular}{|l|l|l|l|l|l|}
\hline Lab code & $\begin{array}{l}\text { Composite } \\
\text { depth below } \\
\text { the sediment- } \\
\text { water } \\
\text { interface }(\mathrm{cm})\end{array}$ & Description & $\begin{array}{l}{ }^{14} \text { C age } \\
\text { (years } \\
\text { BP) }\end{array}$ & $\begin{array}{l}\text { Error } \\
\text { (years) }\end{array}$ & Cal yr BP $\pm 1 \sigma$ \\
\hline CAMS-160886 & 152 & pollen & 2990 & 30 & $3195 \pm 126$ \\
\hline CAMS-160879 & 360 & charcoal & 4740 & 100 & $5395 \pm 310.5$ \\
\hline CAMS-160878 & 536.5 & charcoal & 7810 & 110 & $8696 \pm 282$ \\
\hline CAMS-165605 & 650.5 & pollen & 10200 & 40 & $11915.5 \pm 160.5$ \\
\hline CAMS-165606 & 701 & pollen & 11655 & 35 & $13496.5 \pm 70.5$ \\
\hline CAMS-165607 & 751.5 & pollen & 15780 & 430 & $19194.5 \pm 910.5$ \\
\hline CAMS-160885 & & pollen & $>22800$ & & $\begin{array}{l}\text { not used due to } \\
\text { high uncertainty } \\
\text { because of } \\
\text { insufficient } \\
\text { carbon }\end{array}$ \\
\hline & & & & & \\
\hline
\end{tabular}



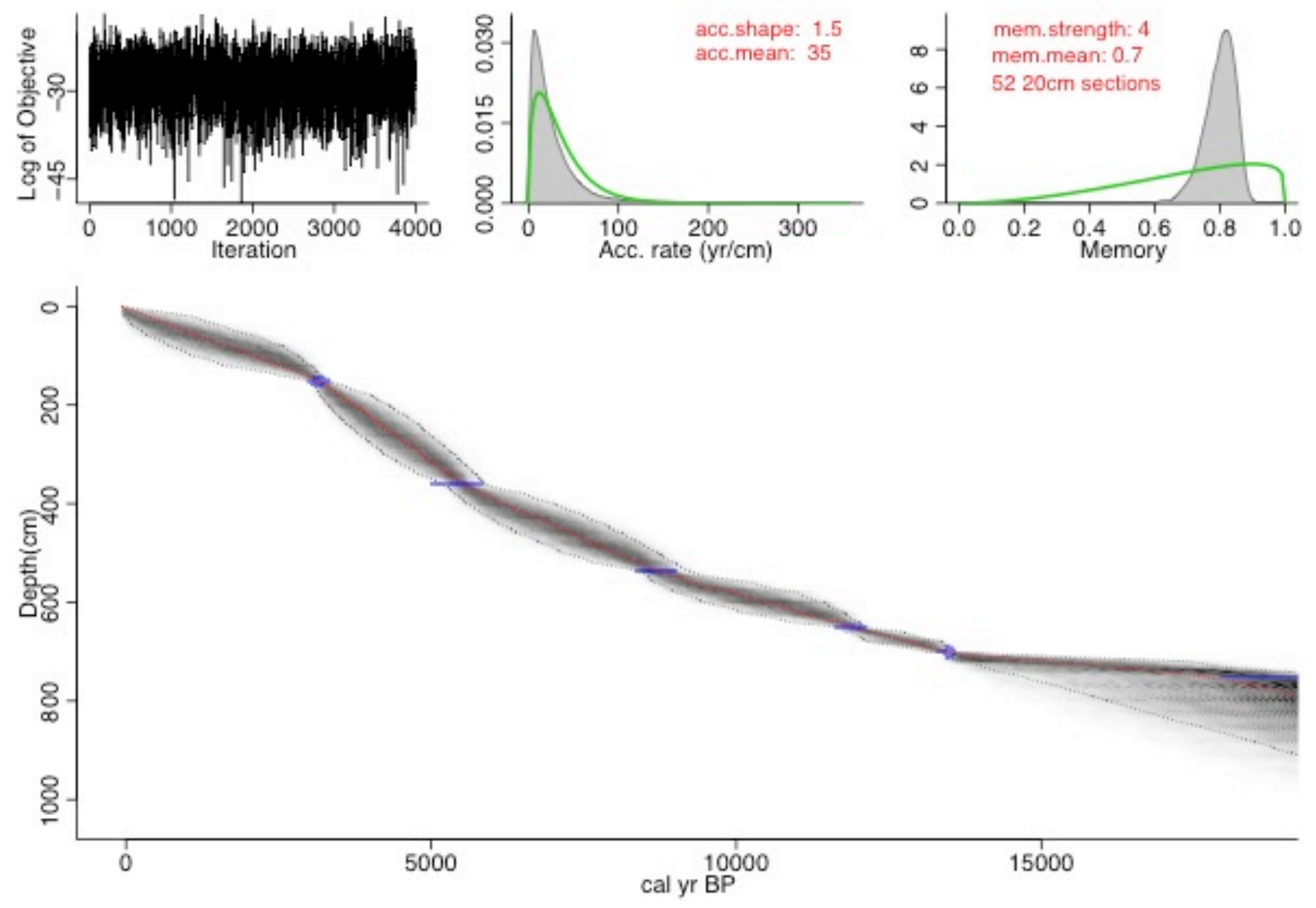

Figure 2 - JJWilliams et al 1-column fitting. Colour on web 

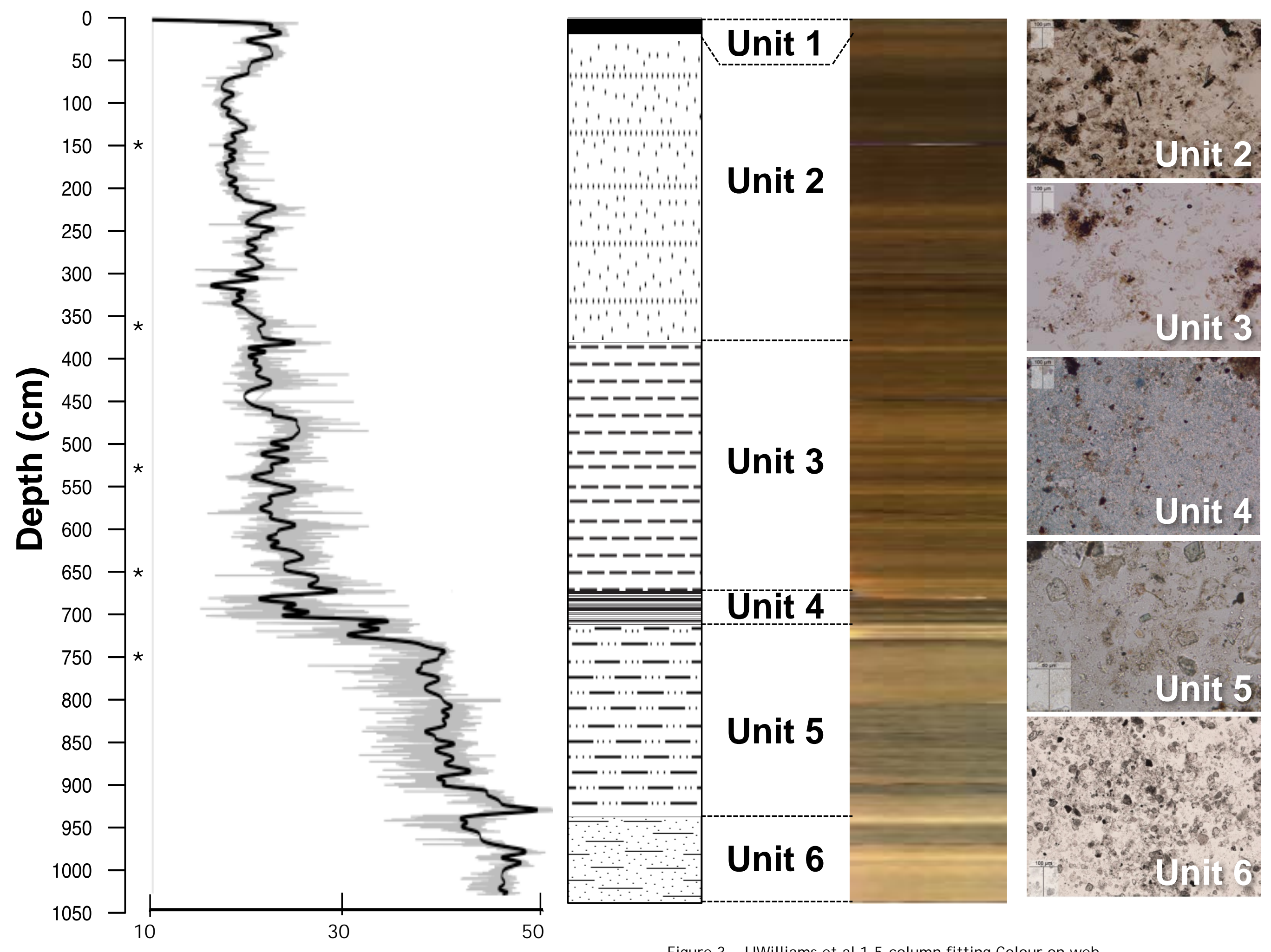

Figure 3 - J J Williams et al 1.5-column fitting Colour on web 


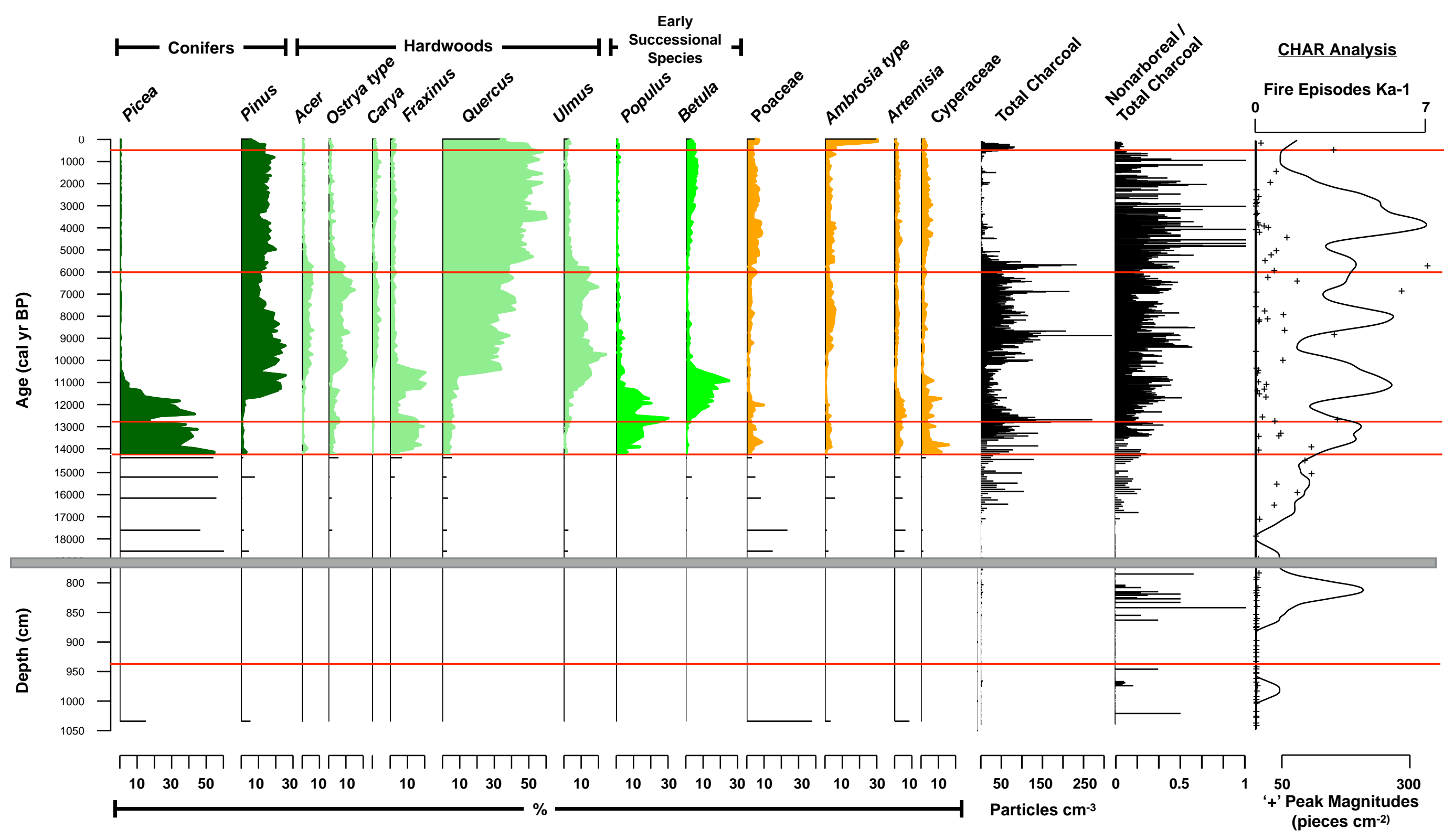

Figure 4 - JJWilliams et. 2 column fitting, colour on web 


$$
1
$$




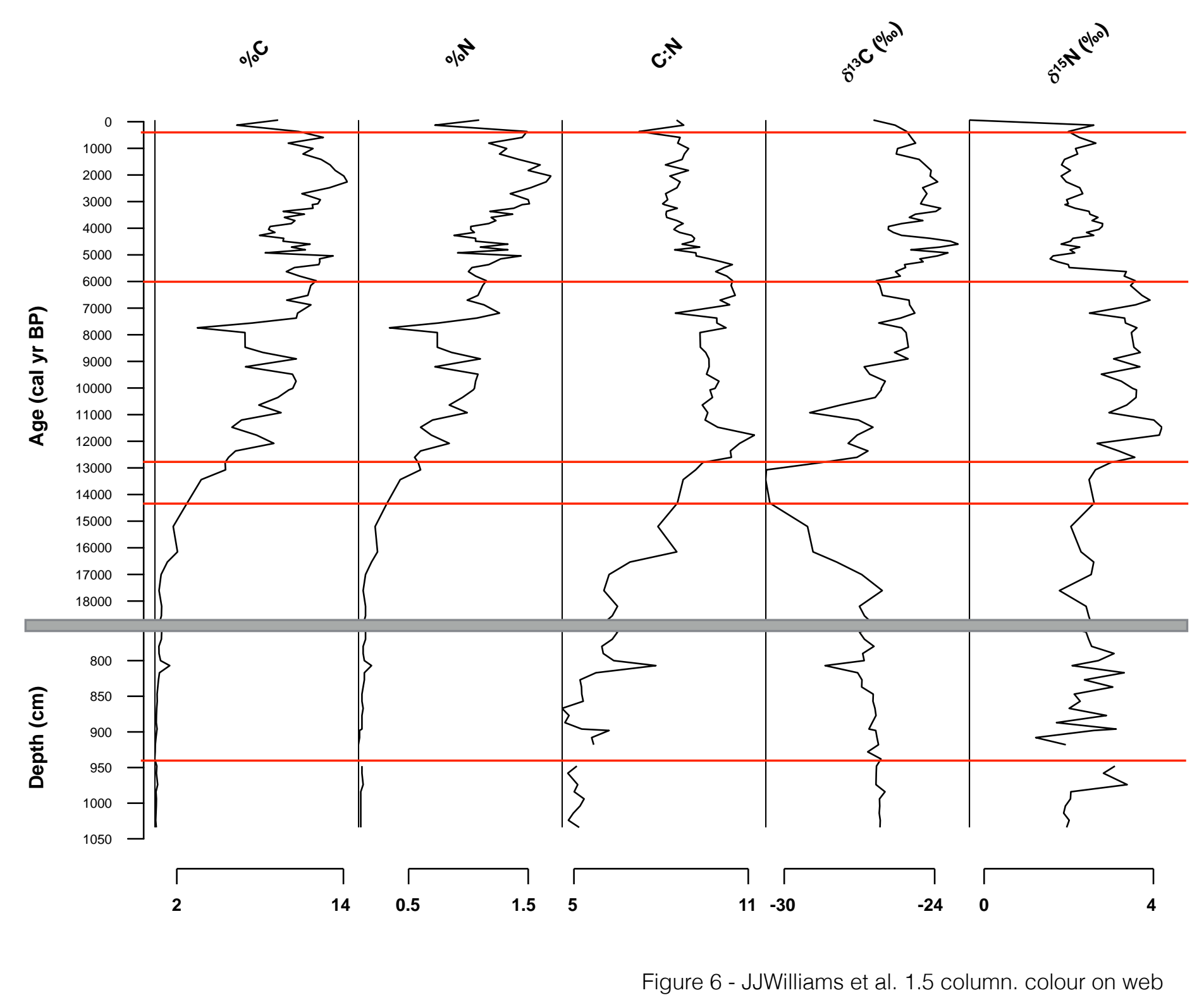

